\title{
Homo Anglicus / Homo Scotus: The Naturalisation of England and Scotland in Scottish Political, Economic and Social Discourse in Recent Times
}

Homo Anglicus / Homo Scotus : la naturalisation de l'Angleterre et de l'Écosse dans le discours politique, économique et social au cours des dernières décennies

Didier Revest

\section{Q OpenEdition Journals}

\section{Electronic version}

URL: http://journals.openedition.org/etudesecossaises/796

DOI: 10.4000/etudesecossaises.796

ISSN: 1969-6337

\section{Publisher}

UGA Éditions/Université Grenoble Alpes

\section{Printed version}

Date of publication: 15 April 2013

Number of pages: 91-115

ISBN: 978-2-84310-246-2

ISSN: $1240-1439$

\section{Electronic reference}

Didier Revest, "Homo Anglicus / Homo Scotus: The Naturalisation of England and Scotland in Scottish Political, Economic and Social Discourse in Recent Times", Études écossaises [Online], 16 | 2013, Online since 15 April 2014, connection on 16 March 2021. URL: http://journals.openedition.org/ etudesecossaises/796 ; DOI: https://doi.org/10.4000/etudesecossaises.796 


\title{
Homo Anglicus / Homo Scotus: The Naturalisation of England and Scotland in Scottish Political, Economic and Social Discourse in Recent Times
}

\begin{abstract}
"For the point is this: not that myth refers us back to some original event which has been fancifully transcribed as it passed through the collective memory; but that it refers us forward to something that will happen, that must happen. Myth will become reality, however sceptical we might be."

Julian Barnes, A History of the World in 101/2 Chapters, London, Picador (in association with Jonathan Cape), 1990 (1989), p. 181.
\end{abstract}

The Scottish National Party came into existence in February 1934. Its core aim was, and has been, to put an end to the 1707 Union with England (and Wales), and resist what they saw, and have seen, as assimilation with English organisations. Typically, speaking in the House of Commons during the debate on the Scotland and Wales Bill on 14 December 1976 (Hansard, vol. 922, c. 1358), George Reid, Scottish National Party MP for Clackmannan and East Stirlingshire, defended the creation of a Scottish Assembly thus:

There are three major determinants of what is happening in Scotland. The first is perfectly obvious: that we are a nation in our own right. We were never put down by conquest but came to this House free and equal partners, after a thousand years of independent history. If the Commissioners of 1707 had wanted to "un-Scotch" us they would have done away with the institutions which are the main carriers of Scottish nationalism and nationality. What is the difference between Merseyside, Tyneside and Scotland? Hon. Members comparing Merseyside with Scotland are not comparing like with like. There is no separate church system on Merseyside. There is no separate legal system on Merseyside, there is no separate schooling system on Merseyside, no separate university system, no separate administrative system. There is a difference of degree and kind. 
The Act (or Treaty) of Union of 1707 had indeed laid down that, to preserve her nationality despite incorporation, Scotland would retain for all time certain key institutions: the Scottish legal system (which was to form an autonomous entity within Britain, a division however never strictly adhered to in practice); the Presbyterian Church of Scotland (the "Kirk"); the Scottish educational system (which means Scotland has her own universities, e.g. St Andrews); the "royal burghs" (partly autonomous local authorities). The Scottish Office, too, was set up in the late 19th century to coordinate local government action (on the rise throughout the 20th century) and respond to the demand for more autonomy in Scotland. The above statement, however, is wanting for a number of reasons.

In the same way as the increase in functions just referred to was never contemplated in the 1707 legislation (and was therefore in the main decided by Westminster), Scotland participates in the Scottish and British arenas simultaneously through the ministers and administrators of the Scotland Office, the Scottish MPs, the Scottish sections of British pressure groups, in addition to many other key elements shared with England (the banking and economic system, religion, the Welfare State, the army, the structure of government, and so on). Logically, most revenue, social security and economic legislation, too, has been British. Likewise, under the current devolution settlement, Scotland has in fact two governments, with (to cut a long and complex story short) separate responsibilities: one Scottish (for devolved matters: e.g. the NHS), one British (for issues affecting the whole of the UK: e.g. defence).

It is relatively easy to see through Reid's rhetoric for other, deeper reasons. It is likely that if he was right about the inevitable and automatic impact of national institutions on the nationals themselves, then Scots can equally be seen as not very dissimilar to the English with whom they have also, and crucially, shared many other institutions for the last 300 years or so (which probably goes a long way towards explaining why many in Scotland - as I write, a clear majority - still do not want out of the UK). A more abstract way of presenting the question would be: if Scots are "plastic" enough to be moulded by one set of institutions, are they not likely to change also in response to another one?

To be fair to Reid, he had in fact, earlier that year, said almost exactly the same thing as above, but had this time emphasised the economic dimension ${ }^{1}$ :

1. "Devolution [Scotland And Wales]", Hansard, House of Commons Debates, 19 January 1976, vol. 903 , c. 1042. 
I can understand the suspicion with which Members from the English regions view the Government's proposals. The problems of urban decay and industrial decline in Scotland have the same origins as those on Tyneside and in the North of England. However, there is a difference in kind. A region is simply not a nation. There is no devolved administration, no separate law, Church or educational system on Tyneside. A nation has wider freedom of action than a region. ${ }^{2}$

The link between institutions such as the Church and the economic situation is nevertheless far from clear, and while nation status may mean more freedom of action, such action and economic success do not necessarily go hand in hand (as we see all too often the world over). Making hay over Scottish specificity can therefore easily go awry. As self-determination is the SNP's raison d'être, however, the party has had but two options: more of the same, in the same terms, or-more subtly-more of the same mixed in with other elements, i.e. a certain vision of "England" and "the English". They can, indeed, be made to serve as foils to Scotland and the Scots, as has increasingly been the case since at least the early 1980s that saw many parts of Scotland reel under the strong socioeconomic medicine administered by successive London-based Conservative governments. But even then, as we shall see, problems (both factual and politico-philosophical) arise.

\section{Beyond the pale}

When the summer 2011 riots took place across English cities, Scotland's First Minister Alex Salmond complained to broadcasters that referring to the riots as being UK-wide risked increasing copycat ones in Scotland and damaging Scotland's reputation as a tourist destination, a view shared by SNP MSPs, ${ }^{3}$ as well as bloggers. Speaking on BBC Radio Scotland, he also pointed out that "We know we have a different society in Scotland" (Carrell, 10 August 2011).

A different society with a different ethos. In the January 2012 Hugo Young lecture for the Scott Trust in London, the First Minister argued

2. The recession had in fact hit harder in many parts of England. From November 1970 to November 1975, the percentage rate of unemployment had increased from $5.4 \%$ to $6.6 \%$ in Glasgow, from $3.5 \%$ to $4.7 \%$ in Paisley, from $2.3 \%$ to $4.7 \%$ in Manchester, from $5 \%$ to $7 \%$ on Tyneside and from $4.7 \%$ to $10 \%$ in Liverpool. In November 1975, overall unemployment in Scotland stood at $5.9 \%$ (as in the South-West of England) while it was 5.2\% in the West Midlands, $6.2 \%$ in the NorthWest of England, and 6.7\% in the North of England ("Unemployed Persons", Hansard, House of Commons Debates, 16 December 1975, vol. 902 c. 593W).

3. $\mathrm{MSP}=$ Member of the Scottish Parliament. 
that Scotland was already more socially liberal than the rest of the UK (e.g. the Scottish elderly, contrary to their English counterparts, enjoy free personal care, and there are no prescription charges, such services providing, the First Minister insists, a sense of an inclusive society). That is why, importantly, an independent Scotland would champion the welfare state and health service, and offer English voters a model for a more socially just and tolerant society, helping the centre-left in England revitalise itself (Carrell, 23 January 2012).

The "us and them" approach goes back many years and has had many faces. During a BBC Scotland programme after the 1987 general election, Scottish historian (and future MSP) Christopher Harvie denounced the fact Margaret Thatcher personified all those English features (e.g. snobbery and selfishness) Scots had always hated (Civardi, 2000, p. 219). As a matter of fact, the personification of England and Scotland has grown apace ever since. Recently, in a newspaper column, SNP MSP Joan McAlpine compared the relationship between Scotland and England to an abusive marriage (Swanson, 8 March 2012). Likewise, during the 12 January 2012 Question Time programme on BBC 1, SNP Nicola Sturgeon, the Deputy First Minister, pointed out that post-independence, England would lose a "surly lodger" and gain a "good neighbour". 4

The two countries being in essence two different persons, a converging relationship post-independence would be a matter of shared "interests" only. In 2007, Salmond said:

What we both need now are the political and economic powers to make our nations work, to tailor policies to suit our different circumstances and to speak for ourselves in Europe and the wider world - while acting together where out $[$ sic $]$ interests converge. ${ }^{5}$

The message seems to have sunk in to such a degree that, more often than not, the England half of the equation is dispensed with. For example, in the following Christmas message ${ }^{6}$ :

In Scotland we have a shared sense of the common weal, of our collective responsibility to each other, empathy, perhaps it is the best thing of all about Scotland. Our spirit of community is a national asset at all times, but it is

4. Alex Salmond uses exactly the same phrase in his "Foreword" to Your Scotland - Your Referendum A Consultation Document (25January 2012; see <www.scotland.gov.uk/Publications/2012/01/1006/>).

5. Ian Swanson, "England unfairly treated by 'stale Union' says Salmond", Edinburgh Evening Newes, 20 March 2007.

6. "Alex Salmond hails 'spirit of community' in Christmas message", The Scotsman, 23 December 2011. 
very, very important during the festive period, and during times of economic uncertainty.

Strangely, both within Scotland and outside, the ambivalent attitude of the other political parties, Labour to begin with, has lent the Nationalists a hand. In the Labour Party's manifesto for the 1997 general election, Tony Blair, though he did genuinely intend to remove "the threat of separatism" (his words) through devolution, said:

I believe in Britain. [...] The United Kingdom is a partnership enriched by distinct national identities and traditions. Scotland has its own systems of education, law and local government. (Weight, 2003, p. 697)

To some extent this amounted to using one of the SNP's core arguments for autonomy.

Tony Blair was naturally rather reluctant to introduce devolution, a commitment he had "inherited" from his predecessor, John Smith. But among those who were not, Labour MP, and first Scottish First Minister, Donald Dewar (known as "the Father of the [Scottish] Nation") must stand out. No doubt he believed in unionism, and sincerely thought devolution would improve the way the UK was run. ${ }^{7}$ But from an early stage, he nevertheless drew a line in the British sand between Scotland and the rest of the country, for example when he explained that he could only argue for the case for Scottish devolution given that "I am in Scotland. I have a problem [...] people in [other] areas do not argue for it. That is their business". ${ }^{8}$ In 1992, he agreed with Prime Minister John Major that making the government more responsive to the needs of Scotland must not damage the Union, and said: "[...] I emphasise that Scotland's future should be as a full and equal partner in the United Kingdom." 9

Now, interestingly, the SNP do use the phrase "equal partner" too, and to them, in the name of self-determination for Scotland (which they see as a separate entity with specific needs and values), it can only mean independence. And they have a point. "Equal partners", contrary to the phrase "interacting individuals (or groups)", fundamentally suggests that Scotland and England exist side by side, like two persons ("partners"). Such discourse allows for little fluidity in the relationship between the populations comprised by those two entities.

7. In his speech at the annual conference of the Labour Party on 3 October 1997 (he was then Secretary of State for Scotland), D. Dewar said: "We must ensure that this parliament is bedded down, fits in with, meshes with Westminster."

8. "Scotland Act 1978 [Repeal]", Hansard - House of Commons Debates, 20 June 1979, vol. 968, c. 1378 .

9. "Privatisation", Hansard - House of Commons Debates, 11 May 1992, vol. 207, c. 458. 
While others in the Labour Party spoke about a "New Unionism", Dewar referred to "independence in the UK" (Mitchell, 1998, p. 136). When (less than two weeks after the Scotland Bill had received Royal Assent) he spoke in St Andrews on 30 November 1998 ("The Scottish Parliament: The Challenges ahead"), he duly rounded on the Nationalists who did not realise how integrated the Union was and how dangerous independence would be, for example in terms of Scotland's finances and defence industries. But, otherwise, and in essence, he used the same sort of language as his opponents:

We have a Parliament again. [...] We have a Scottish Parliament because we are Scots and because Scots want to govern their domestic affairs here in Scotland, a nation with an identity. [...] What makes our country special is the strength of our values. Our commitment to equality of opportunity and social justice.

Small wonder then if deputy First Minister Nicola Sturgeon, when speaking at the annual conference of the SNP in Inverness in October 2011 after announcing there would be an independence referendum in Scotland (earmarked for late 2014), went so far as to paraphrase Dewar himself when he announced there was going to be a referendum on devolution in the late 1990s: "I like the sound of that. I really, really like the sound of that." 10

Malcolm Chisholm (Labour MSP for Edinburgh North and Leith, and a former Scottish Executive minister) is another interesting case. He had been opposed to devolution in 1979 (and was denounced in May 1997 as one of the "abominable no men" of Scottish politics by Allan Macartney, MEP and SNP deputy leader). He changed his mind afterwards. He has recently even come out in favour of "a much stronger devolution model, particularly in the area of economic and financial powers" for Scotland, a move supported by many trade unions and a prominent member of the Scottish Conservative Party, Murdo Fraser. This is how he has justified his position:

[...] but we have to go beyond them in making a positive case for the United Kingdom. The starting point is that we are equal nations choosing to come together and that equality means we in Scotland can make demands in a claim of right for the powers and responsibilities that we want. (Chisholm, 24 November 2011)

10. "SNP conference: Scots will vote for independence - Sturgeon", The Scotsman, 21 October 2011. 
Former Scottish First Minister Henry McLeish (2000-2001), who favours full financial powers for Scotland, has gone so far as to warn the British government that "It's a Scottish matter and [...] Westminster should keep out of the referendum and not meddle" (Whitaker, 22 November 2011). H. McLeish crucially starts from the (typically nationalist) assumption that, in post-devolution Scotland, identity politics is playing an increasingly important role for reasons that, to him, are obvious: "People love their country and want identity, nationality and diversity better recognised; the maximum number of powers exercised by the Scottish Parliament; to say No to independence, and at the same time, remain part of the UK." (McLeish, 28 January 2012)

But these cases are merely the tip of the iceberg. As Scottish academic J. Mitchell (1998, p. 122) has explained:

There is now a deeper divide within unionism than in the past. Unionist supporters of devolution see it in terms similar to the SNP view of independence. Self-government, rather than unionism, is the motivation and language of devolutionists. The "Claim of Right", signed by almost all Labour MPs and all Liberal Democrat MPs in 1989, is a document which argues for reform of the state but uses strikingly nationalist language and arguments. It is Scotland's "right" which is being asserted.

The Claim of Right for Scotland was presented to the Campaign for a Scottish Assembly on 6 July 1988. The starting point of the Claim was that (see p. 14 of the document) the Union had become "a threat to the survival of a distinctive culture in Scotland". A passage on page 6 states that the United Kingdom is "a political artefact". As a matter of fact, the so-called Labour Action Group, formed in 1990, even urged Labour to become more nationalist to prevent the electorate swinging against the party, which to many Labour activists at the time was not perceived to be contradictory since they had actually joined forces with SNP grassroots members in their "Scotland United" fight against the poll-tax, deindustrialisation and the restructuring of the manufacturing sector imposed by the Conservatives.

Unsurprisingly, the Scottish Constitutional Convention blueprint for devolution, "Scotland's Parliament, Scotland's Right (Report to the People of Scotland)", approved and published in the autumn of 1995, shared the same basic assumption as the Claim:

Scotland $[\ldots]$ has a distinguished and distinctive structural heritage, evident in Scotland's legal system, its educational system, its social, cultural and religious traditions. These things are the very fabric of Scottish society $[\ldots]$. 
This notion of discontinuity between England and Scotland (which had always been at the heart of the SNP's vision) had by then become the driver of the political agenda.

Devolution naturally remains an undeniable step towards a fairer democracy, with decisions formerly made by the Scottish Office-i.e. a department of the British government - now taken by a parliament directly accountable to the people of Scotland; at the same time it is a far cry from internal autonomy. It has however been criticised for being "a project of the parts, not the whole", or in the words of Hugo Young "a demand of Scottish politics, not a philosophy of British politics", 11 i.e. a political "addendum" based first and foremost on the notion of Scottish exceptionalism (her separateness from England). As Professor Charlie Jeffery, director of the Academy of Government at Edinburgh University, has underlined, there has been next to nothing in terms of shared UK-wide purpose, and the reliance on bilateral relations between governments has reinforced this (Jeffery, 6 May 2011). Hence, to sort out current higher education problems, such as funding gaps between the UK nations or staff recruitment (let alone problems of social justice), Alan Trench's call for "a more structured approach" and "more routine coordination at official level" to deal with the implications of a devolved Britain (Trench, 2009, p. 37).

Hyped up by the media, the "England-and-Scotland-are-poles-apart" vision has actually been used to describe what was going on in many different fields, however remote from politics and the economy. Will Carling, who captained the England Rugby Union team at the time, came under intense pressure in the build-up to the Grand slam decider against Scotland at Murrayfield in March 1990; as he looked very self-confident, he could be nothing but "Thatcher's captain". Yet, how could he? He had never been into a polling station in his entire life. His team-mate, Brian Moore, the English hooker, another of "Thatcher's boys" (some of whom, like Paul Rendall or Mick Skinner, were working-class through and through), actually sympathised greatly with the Scots on account the introduction of the poll tax, ${ }^{12}$ which he believed to be appalling. This

11. "The pledge that Blair must be cursing", The Guardian, 11 February 1997.

12. Officially known as the "community charge", this new tax was to replace the rating system and be paid by all adults over the age of 18 within the same local authority, with everybody paying the same amount, which a majority of people found very regressive (see Alan Sked and Chris Cook, Post-War Britain - A Political History, London, Penguin Books, 1993 [4th edition, 1979], p. 464). Incidentally, it was invented by a Scot, Douglas Mason (1941-2004), and introduced into Scotland in 1988-89, ahead of the rest of the UK, by Scottish Conservative politicians (see Jacques Leruez and Pierre Morère, L'Écosse contemporaine - Politique, société, économie, culture, Gap and Paris, OphrysPloton, 1995, p. 40-2). It was finally abolished under J. Major, in 1992, and replaced by a fairer system, known as the "council tax". 
would have actually pleased Jim Telfer, one of Scotland's coaches, who hated the London-based millionaires as much as he hated the clan chiefs and aristocrats living of the Scottish borders, and thought he had more in common with people from the north of England than from the north of Scotland. Interestingly too, after his team's victory, David Sole, the Scottish skipper (who was born in Buckinghamshire, lived in Hertfordshire when a small boy and later on played for Bath as a prop for years), gave his jersey to Peter Phillips, first grandchild of Queen Elizabeth. Unlike Carling, who turned down the offer, Sole also went to Downing Street at Mrs Thatcher's invitation (English, 2010, pp. 12, 14, 17-8, 40, 85, 165, $176,205,203,215,221,223)$.

There may indeed be more in the England/Scotland relationship than has been dreamt of in some "philosophies".

\section{Beyond good and evil}

Some of the above statements would have baffled many English people, in particular those living in the North and in inner cities all over England, who could see, at first hand, the havoc wreaked by Conservative policies. Liverpool easily proves the point. In the aftermath of the early July 1981 Toxteth riots, Cabinet ministers (Geoffrey Howe, Chancellor of the Exchequer, prominent among them) advocated a "managed decline" of the city, and went so far as to raise the prospect of its partial evacuation. To them, indeed, decline was largely self-inflicted and the locals therefore deserved little help or consideration. As a matter of fact, instead of getting the $£ 100$ million a year of new money for two years which Environment Secretary Michael Heseltine insisted upon, the city was offered a paltry $\mathcal{E} 15$ million while it was thought better to concentrate on the more promising West Midlands (Travis, 30 December 2011).

Mrs Thatcher may not have "got" Scotland, but she did not "get" huge swathes of urban England either. She saw depravity where unemployment, poverty and community breakdown (due in large part to rehousing programmes and changes in the composition of the population and in police tactics) were rampant; in the Toxteth area, around 1980, unemployment, as underlined by the Rector of the Toxteth Team Ministry, afflicted nearly $25 \%$ of the white community and nearly $45 \%$ of the black community whereas very few school-leavers could find a job (Bedford, 1982, pp. 22-3, 37, 75-6, 104). And the pain has lingered on. The Halewood area, south of Liverpool, is still classified as one of the most deprived areas in Europe; it has never recovered from the closure of a sweep of factories in the late 1980s, like the nearby town of Speke. 
The local NatWest, the town's last remaining bank, was due to close in April 2012 because providing banking services in an area with such high levels of unemployment and low-paid work was simply not profitable. In 2011 , youth unemployment increased by $10 \%$, and a food bank opened for the first time in the area (Gentleman, 21 March 2012).

In much the same way, the government virtually turned their backs on inner-city areas in the South. In February 1983, the unemployment rate in Hackney, London, was as high as in devastated one-industry towns such as Ebbw Vale or Irvine or, for that matter, Corby in Northamptonshire (Harrison, 1988, p. 114). London-wide, the number of electricity cut-offs rocketed from 11,016 in 1978 to a staggering 37,648 in 1980 (Harrison, 1988, p. 162). Furthermore, according to Census 1981 - Economic activity in Great Britain (HMSO, 1984, Map D), the number of unemployed teenagers (i.e. "economically active persons aged 16-19 out of employment") was highest ("21\% and over") not just in South Wales, Liverpool, Strathclyde and South Yorkshire, ${ }^{13}$ but also in Central London, North Kent, the southern part of the Isle of Wight, the western tip of Cornwall and the Great Yarmouth area.

By the worst point of the 1990s recession, in the Spring of 1993, the unemployment rate in London was 13.2\% compared with $10.4 \%$ in 1984, when the recession had primarily hit the North, the Midlands, Wales and Scotland. In the latter, it was now $10.2 \%$ (i.e. the UK national average), down from 15\% in 1984 while in the North of England it was $11.3 \%$, down from 16.3\% (Convery, 1997, p. 174).

There is little doubt that by the late 1990s Scots fared worse on some parameters: risk of premature death, especially in the Glasgow area (as is still the case today), or more excess winter deaths; however, in 19992000, there were more children living in households with below $50 \%$ mean income (after housing costs) in England (32\%) than in Scotland $(29 \%)$, while the proportion of English children living in workless households in 1999 was also higher (18\% as against 17\% in Scotland). Finally, if Glasgow was over-represented in the table showing the ten poorest British parliamentary constituencies in 2000, it also featured six English inner-city areas, e.g. Birmingham Ladywood and Manchester Central (Garnham et al., 2001, pp. 179-80, 181, 184).

The repeated calls for devolution to England and the English exemplify the complex picture (economically and socially) that emerges when one delves into the fragmented nature of English society at the time. A case in point was of course the North East of England, which had suf-

13. For the situation in the Sheffield steel mills and mining industry more generally, see e.g. Coleman (1988, p. 17-9). 
fered more from neglect and the economic recession than any other UK region (except for Northern Ireland), and was often described as a colony dominated by an imperial heartland (Tomaney, 1999, pp. 73-6).

In truth, even the phrase "heartland" is problematic, as suggested above. More often than not, London has been depicted as the source of all evils: it is affluent, arrogant and domineering. But this is a sweeping generalisation. London means more than just the UK government and high finance. Job growth across London for example does not appear to be benefitting many of its residents. For instance, some of the wards of Southwark tell a story which quite a few in places such as Glasgow would instantly recognise. In the mid-2000s, female unemployment in that inner-London district was double the national average; in the East Walworth ward, as many as 38\% of households had no working adult (Escott et al., 2006, pp. 4, 7, 11). More generally, in the late 2000s, Inner London had the highest proportion of children living in workless households of all UK regions. The UK capital also has a disproportionately high number of people living in temporary accommodation (Parekh et al., 2010, pp. 56 and 99). Unsurprisingly, $38 \%$ of all London children are officially poor while the employment rate for the city as a whole was $68.4 \%$ in 2010, i.e. two points below the British average (Appert $e t$ al., 2012, p. 28). Finally, according to academic Daniel Dorling in Fairplay: A Daniel Dorling Reader on Social fustice, the richest tenth of adults in London have 273 times the wealth of the poorest tenth, compared to 96:1 across England (Hassan, 17 March 2012).

Did a majority in England vote for this? Hardly. In early 1990, Martin Redmond, Labour MP for Don Valley, attacked the Conservative government plans for the introduction of competition into health care provision. ${ }^{14} \mathrm{He}$ emphasised that both staff and local communities "around the country" (e.g. Tyneside, Doncaster, Reddish [in Greater Manchester], York and Plymouth) massively rejected the move. His subsequent plea for more democracy had clear "Claim of Right" overtones:

Unlike the Labour Government of 1945, who brought the NHS into being and who had a mandate from the electorate to do so, this Government have no mandate for the introduction of opted-out hospitals. Nowhere in the Conservative party's election manifesto were these changes mentioned. [...] The Government $[\ldots]$ want to make hospitals more responsive to local needs. Surely the logical step would be to elicit the views of those most directly involved - the staff, the patients and the community.

14. "National Health Service Hospitals [Opting Out]", Hansard, House of Commons Debates, 21 March 1990, vol. 169, cc. 1121-2. 
It is therefore logical that, throughout Britain, between the early $1980 \mathrm{~s}$ and the mid-1990s, people expressed a rising preference for increased taxation and more spending on health, education, and social benefits, from $32 \%$ in 1983 to $61 \%$ in 1995 , with only $5 \%$ then saying that they wanted both taxes and spending cut (Hills, 1997, pp. 240-2). In much the same way, by the mid-2000s, English public opinion on tuition fees, free personal care for the elderly, levels of taxation and public spending was quite similar to that in Scotland. In other words, English opinion was consistent with Scottish policy, and not with the choices made by the Westminster Parliament (Jeffery, 2005, p. 124).

This still holds true today. According to a recent ICM Research poll (17-19 February 2012), a majority of respondents, 52\%, said that the bill introduced by the Cameron government to overhaul NHS management, increase competition and give family doctors more financial responsibility, (i.e. a clear drive to extend medical competition), should be dropped. Only 33\% believed Parliament should go ahead with the bill. The 19-point margin against the legislation was mirrored across all social classes and regions, as well as among male and female voters (Clark, 20 February 2012). It seems then that contrary to Alex Salmond's wish (see above), an independent England would not need Scotland as a "beacon" of social democracy.

The fact the British state is run from England/London and can thereby only be "English" is half the story at best. As has been pointed out about the first Thatcher government, "here was a government elected by only one-third of the electorate and which no less than $56 \%$ of those who bothered to vote [in 1979] did not want". In 1983, Mrs Thatcher's party was returned to office on a lower share of the vote $(42 \%)$, but its majority in terms of Westminster seats increased from 43 to 144. Because of the "first-past-the-post" system, the impression was given that the map of England had in the main turned blue and that England herself had become Tory. This could not be further from the truth: the votes of the $25 \%$ who voted for the Liberal-SDP Alliance in 1983 translated into only 4\% of seats in the House of Commons. In fact, one may finally argue that, paradoxically, as seen above, Mrs Thatcher's huge majority turned out to be detrimental to quintessentially English values, such as the family, individual freedom, or local authority autonomy. They were all weakened by poverty, rising crime and unemployment rates, and central government intervention (Harrison, 1988, p. 410 for the quote and pp. 435-6; Bugler, 1994, pp. 23-41).

If anything, then, Thatcherism consisted of traits and characteristics found in England (but not only, see below), whose sum total nonetheless was far from coterminous with the whole of England. Thatcher could 
therefore only be seen as an archetype by those who chose to ignore this complexity: an archetype indeed is an ontological conception that exists outside of time (Hackett Fischer, 1970, p. 150).

Consequently, David Torrance certainly has a point when he insists that Thatcher was resented by many in Scotland not only on account of her general style, her economic choices and the poll tax, but also because the feeling was reinforced by opposition spin and media repetition. Moreover, funnily enough, many of the things now cherished and taken for granted by most Scots (e.g. consumer choice when choosing a new telephone or utility supplier) are derived from the deregulation, the free market, introduced in the 1980s (Torrance, 2009, pp. 279-80).

A BBC 4 programme ("Thatcher and the Scots") broadcast on 14 September 2009 reached the same sort of balanced verdict: the Scots' vision of M. Thatcher was a little too stereotypical. Some of her decisions (such as when, through the 1980 Housing Act she gave council tenants the right to buy their flats), though denounced as smacking of individualism by many, ${ }^{15}$ actually went down particularly well in Scotland where a majority were not home-owners. Owner-occupation in Scotland over the early 1980 s-early 2000 s rose from $38 \%$ to $63 \%$, closing the gap on the rest of the UK, where owner rates jumped from $59 \%$ to $70 \% .{ }^{16}$ By the mid-2000s, the overall average rate of home-ownership was nearly $66 \% .{ }^{17}$ Besides, there continued to be significant unmet demand. ${ }^{18}$

More generally, one can hardly deny the fact that right-wing ideologies/choices are alive and well in Scotland. The SNP did largely become a party with broadly left-wing supporters in the 1980s (Mitchell, 1998, p. 134), but times seem to have changed, as illustrated by the fact many right-of-centre voters choose the SNP these days (Trench, 4 October 2011). A pro-business policy (which involved seeing globalisation as an opportunity, as Tony Blair and New Labour did) was in fact adopted in the wake of the party's defeat in the 1999 election; up until then it had been far more pro-public expenditure (Cuthbert and Cuthbert, 2009, p. 109).

SNP policies are indeed mixed with elements of neo-liberalism (Hassan, 2009, p. 4-6). For instance, in the last Parliament, SNP MSPs

15. See e.g. Raphael Samuel, "Introduction: exciting to be English", in Raphael Samuel (ed.), Patriotism - The Making and Unmaking of British National Identity. Vol. I: History and Politics, London, Routledge, 1989, p. xxxix.

16. "Scots home ownership doubles", BBC Neres, 25 January 2003.

17. On the whole, almost half a million homes have been bought in Scotland since the 1980s. See Scott Macnab, "SNP set to scrap right to buy council homes in Scotland", The Scotsman, 8 June 2012.

18. "The changing face of home-ownership in Scotland", London, Council of Mortgage Lenders, 2006, <www.cml.org.uk/.../04Thechangingfaceofhome-o...>. 
may have generally maintained a centre-left position (they attacked $\mathrm{PFI}^{19}$ and privatisation), but at the same time "promoted low business taxes and light-touch regulation of financial services on the Irish model and were silent on excessive remuneration for top executives". In early 2010, the Scottish education secretary, Michael Russell, ${ }^{20}$ said the government supported councils giving greater flexibility and control to schools. ${ }^{21}$ The SNP Government is also said to have "shared Gordon Brown's fear of antagonising the rich" (Lindsay, 2009, p. 103). Finally, targets for reducing income inequality, for instance, have not been provided (Maxwell, 2009, p. 129). Hence the phrase used by quite a few experts to describe the SNP's vision: "neo-liberalism with a heart" (Cuthbert and Cuthbert, 2009, p. 106-7).

Likewise, the current SNP government may be against using the private sector to deliver public services, but their budget priorities have been to freeze council taxes and do away with business rates for small businesses. Recently, Alex Salmond even met with News International boss Rupert Murdoch and is reported to have discussed with him cutting Scotland's rate of corporation tax from the current $26 \%$ to $10 \%$ in return for BSkyB moving its headquarters to Scotland (Swanson, 8 March 2012). In fact, as early as the mid-2000s, the SNP had made it clear that they intended to reduce corporation tax to about that level. ${ }^{22}$

If one bears in mind the profile of some within the Scottish government, this is hardly surprising. John Swinney, who has been the Cabinet Secretary for Finance, Employment and Sustainable Growth in the Scottish Government since 2007, previously worked in financial services. Both Jim Mather, the former Minister for Enterprise, Energy and Tourism (May 2007-May 2011), who was educated at Paisley Grammar School, and his successor in the current Scottish Parliament, Fergus Ewing, who was educated at Loretto, an independent school that boasts of being Scotland's oldest extant boarding school, are two self-made businessmen. Alex Salmond himself is a former economist at Royal Bank of Scotland. ${ }^{23}$

19. Private Finance Initiative. Under the PFI, launched in 1992 by the Major government, private finance can be raised for public sector infrastructure projects (bridges, roads, schools, hospitals, prisons, etc.) repayable over a 25/30-year- period. These schemes however are often deemed a huge drain on the public purse.

20. Co-author in 2006 of a book advocating the shrinking of the Scottish state by 40 per cent in the first four years after independence; see Grasping the Thistle: How Scotland Must React to the Three Key Challenges of the Twenty First Century, Glendaruel, Argyll Publishing, 2006, 256 p.

21. D. Lee and F. McLeod, "Mike Russell gives his backing to 'trust' schools", The Scotsman, 15 February 2010.

22. "Why border issue could be barrier to split", The Scotsman, 15 December 2006.

23. Ian Swanson, "UK might slip to the right but Scots still remember Thatcher", Edinburgh Evening Neres, 29 January 2010. 
Neo-liberalism is no recent import either. The London School of Economics (whose best minds in the 1930s attacked Keynes's interpretation of the 1929 crash and, in the name of the market's ability to self-regulate, his defence of state intervention) was one of the two main institutional matrices of British neo-liberalism. The other one was the University of Saint Andrews where from the 1960s was articulated the idea of the primacy of the market and the Powellite notion of a strong state, which ultimately became a key component of Thatcherism (Dixon and Christoph, 2011)

In this respect, the following by a seasoned commentator could hardly be more relevant:

We are faced with two contrasting visions of Scotland. The first is liberal, cosmopolitan, mostly urban Scotland, which believes in equality and sees this as part of the journey of Scotland becoming a modern, mainstream European nation. The second is "Sunday Post", mostly faith-based, conservative Scotland [...]. Many of us still don't quite believe that the modern, pluralist, diverse Scotland we live in really exists. (Hassan, 3 December 2011)

Hence yet another paradox. Policy in Scotland for higher education has been less market-oriented than in England; from April 2008, the graduate endowment (a lump sum or loan the graduate was required to pay back) introduced in 2001 was abolished by the SNP government (Trench, 2009, p. 17). Alex Salmond has always fought for free higher education, insisting this is consistent with what Scottish society stands for. In early 2011, a YouGov poll of 1,135 Scottish adults, however, revealed that $65 \%$ supported the idea that students should make a graduate contribution of up to $£ 4,000$ towards the cost of their studies once they start earning. The poll even showed that $66 \%$ of SNP voters favoured the policy (Peterkin, 21 April 2011).

All the hype about Scottish society being more caring and more of a community than England cannot conceal a much more complex picture either. According to the Guardian's University Guide rankings, in 2010, no Scottish university made it into the top 10 best-performing UK universities on social access, i.e. with the highest number of students coming from working-class families (Davis, 28 September 2010). ${ }^{24}$ Besides, official figures released in late 2011 showed that religious hate crime had

24. As someone has written recently, "the proportion of privately educated students in universities in Scotland is almost identical to that in England: 8.7\% and 8.8\%, respectively. Moreover the proportion of university students who come from the lower social classes is clearly lower in Scotland than in England: 27.9\% compared to 31.4\%, according to data published by the Higher Education Statistics Agency on March 29th" (see A. G., "Spiffy Scots", The Economist, 30 March 2012). 
reached a four-year high in Scotland, with Catholics being targeted in more than half of all cases. The bulk of them occurred in the west of Scotland, a traditional hotbed of sectarian trouble. ${ }^{25}$

Furthermore, figures from the Office for National Statistics show that those employed in health and social work activities in Scotland have fallen from a peak of 401,000 in 2006 to 358,000 today, a drop of $10 \%$, while numbers in England have actually increased from 2,967,000 in 2006 to $3,333,000$ now, a rise of $12 \%$. Likewise, according to a survey by the Centre for Public Policy for Regions, there has been a marked fall in Scotland's spending advantage in health and social services compared with England. In 2006, spending per head of population per year came in at $£ 1,766-£ 252$ more than south of the Border. Scottish spending may now be higher - at $£ 2,089$ per head-but that is now only $£ 157$ more than in England. ${ }^{26}$ This sounds strange in a country highly reputed for its attachment to public services, unless, again, such discourse is (partly at least) fallacious. Interestingly, in an interview broadcast in the BBC 4 documentary mentioned above, Professor Tom Devine, the well-known Scottish historian, pointed out that the middle-classes' defence of the public services stemmed not from their innate philanthropy and antiindividualism, but from (understandably) their fear of losing their jobs.

Finally, with all due respect to Henry McLeish (see above, part 1) and all the others, as things stand, a naturalised vision of the EnglandScotland relationship cannot help us anticipate the nature of the constitutional future of Scotland either. Though 44\% feel that decisions about how the referendum should be conducted are for the Scottish Government alone to take, $51 \%$ accept that the UK government does have some role to play. Actually, none of the possible futures of the England-Scotland relationship (status quo, "devo-plus", "devo-max", independence) is currently attracting a majority of voters; while, generally, there is appetite for more devolution, the most radical steps in that direction also remain the least popular (Curtice, 25 January 2012).

\section{Beyond the usual conceptual dichotomies}

England is not Scotland, and vice versa, but sameness and otherness cut right across them both, as we have seen. The fact is in accordance with the following proposition: the features of nationalism are so peculiar that it is a lot simpler to define them than it is to characterise the "nation"

25. "Religious hate crime 'hits four-year high", The Scotsman, 19 November 2011.

26. "Scotland loses 50,000 jobs in health and social work", The Scotsman, 16 March 2012. 
(Delannoi, 2010, p. 103; Canivez, 2004, pp. 72-3). Or, as Anthony D. Smith has written, nationalism is "an ideological movement for attaining and maintaining autonomy, unity and identity on behalf of a population deemed by some of its members to constitute an actual or potential "nation"" (Smith, 1991, p. 73).

From this sociological and political science perspective, there is yet a host of other interesting lessons to be learnt from the preceding pages, to begin with the fact that the "game of representation" is also a domination exercise (Dupin, 2004, p. 136-7). Indeed, naming from above creates a community (almost) regardless of how the people involved see themselves (Poutignat and Streiff-Fenart, 1995, p. 157). As Ernest Renan underlined in the late nineteenth century, the approach is typical of nationalist movements as they are intent on creating the nation, and can only do so by overlooking crucial facts that do not fit into their vision (Wieviorka, 2001, p. 165). This is known as the "hypostasis" of the nation, the creation of an instantly recognisable "super-individual" (Canivez, 2004, p. 18). This situation, however, allows for little circulation: protagonists do not "act" as full-fledged individuals; they are assigned a specific role from the start, with their loyalty taken for granted (Wieviorka, 2001, p. 21). The moral, of course, is that any discourse on (national) identity is intensely political (in both the narrowest and broadest sense of the word).

Anybody with an interest in Scottish history, or any national history for that matter, ${ }^{27}$ should be aware of this. The history of Scotland in the medieval and early modern periods illustrates the point. The Highlands of Scotland, their culture and ancient clans, which many look upon as quintessentially Scottish today, and which had by the 14th century become a by-word for the history of Scotland as a whole (and the basis of claims to independence from England), were, however, increasingly described by the late 15th century in alien terms by the Lowland elites, Kirk and intelligentsia whose policies and values were exercising a growing monopoly. The 1609 Satutes of Iona for example were not just an attempt to put paid to lawlessness, but also an assault on Gaelic cultural difference, seen as "Irish". At the same time, the plural origins of the people of

27. From the history of Ancient Egypt (see e.g. Claire Lalouette, Le monde des Ramsès, Paris, Perrin, 2007 [2002], p. 140) to that of 19th-century France (see e.g. Pierre Bourdieu, Sur l'État (cours au Collège de France 1989-92), Paris, Eds Raisons d'Agir/Seuil, 2012, pp. 547-9) or early 20th-century Mexico (see e.g. Jean Meyer, Apocalypse et Révolution au Mexique - La guerre des Cristeros (1926-1929), Paris, Gallimard/Julliard, 1974, pp. 23-5). This equally applies to regional history; see e.g. Monique Zerner-Chardavoine, La croisade albigeoise, Paris, Gallimard/Julliard, 1979, pp. 231-41, or Alain Corbin, Le monde retrouvé de Louis-François Pinagot - Sur les traces d'un inconnu (1798-1876), Paris, Flammarion, 1998, pp. 35-8. But Professor Shlomo Sand's The Invention of the Jewish People (trans. Yael Lotan - London, Verso, 2010 [2008], 344 p.) certainly ranks as the best recent illustration of what the notions of "mythistory" and "mytherritory" are all about. 
Scotland-Saxon, Norman, Flemish, etc.-were conveniently underplayed, again not to jeopardise Scotland's sovereignty (Kidd, 1999, p. 12345). The contradiction can be summed up as follows: "Gaelic identity was subordinated to a politics of prescriptive legitimacy"; the coexistence of a powerful critique of Highland culture with a national adherence to ideologies grounded in Gaelic historical myths "stands testimony to an ethnocentrism qualified by an essentially legitimist purpose" (Kidd, 1999, p. 141).

We can probably derive even more fundamental conclusions from parts 1 and 2 above. First, although identity (whatever the form) is the byproduct of a relationship and comparison (Delannoi, 2010, p. 86), there is a danger that, in the process, the two meanings of the word, i.e. (in Paul Ricœur's parlance) idem and ipse, may be collapsed into each other. The former, based on sameness, entails a certain number of "others", of "contraries", whose features are clear-cut (as are idem's). Conversely, the latter, ipse, suggests that selfhood, or individuality, cannot (by definition) be dependent upon sameness, but only upon otherness: otherness then becomes part of "me", part of "us". While sameness means necessary identification or recognition, ipse remains "entangled" with others, whether chosen, loved, known, or not. That is why, in the realm of politics, "friendship" - a key word with the SNP when they speak about the Scotland-England relationship post-independence ${ }^{28}$ - is neither here nor there. What is wanted instead is fairness, that is to say the recognition of plurality (against totalising discourses), which includes "third parties that will never be faces", and thereby precludes "an everybody". This situation may be fraught with contradictions (and we have seen quite a few above), but no genuine democracy can actually exist without them being recognised and institutionalised. Only such a framework has the potential to make one adhere to, or simply acknowledge and respect, what is a priori alien (Ricœur, 1990, pp. 12-4, 140-1, 146-7, 190-1, 215-6, 228, 236, 300, 303, 336; Touraine, 1997, p. 303).

The other pivotal distinction we should also bear in mind is that between narration/narrative and past (or more recent) events. Elias, Foucault and de Certeau have taught us that historians produce nothing but texts, so that History has, in essence, a lot to do with narration. History is naturally real both on account of the object it is after and of the means used to reach that end; but, ultimately, it is the relationship with the object that makes it what it is as a historical object. There can therefore be no simple link between narration and truth, no a priori his-

28. See e.g. Alex Salmond, "An independent Scotland will be a beacon of fairness", guardian.co.uk, 23 January 2012. 
torical object, as the historical text - the end-product - emanates from the mutation undergone by the material as analysed by the historian while he is trying to come to terms with it (through quotes, references, footnotes, hypotheses, and so on). Historical writing, in other words, is like puff pastry: it comprises its past object in the present and gives it meaning in that peculiar context, within that tension (Chartier, 2009, pp. 16, 69, 71-2, 185-6, 200, 290, 348-9; Veyne, 1996, pp. 14-5, 26-7, 49, and $201 \mathrm{ff}$.). However, as we have seen, a nationalist interpretation of the (recent) past tends to give precedence to present concerns and see historical events primarily in that light (Canivez, 2004, p. 25).

Nevertheless, taken at face value, the suggestion that England and Scotland have little in common remains a masterstroke. It tends to do away with the ethical dimension as, when one accepts that one was born into a nation with a specific ethos, there is little one can do about it, almost as if one were not responsible for one's actions (individually and collectively). Even when one presents one's own ethos as superior, one cannot be accused of, at worst, racism, or, at best, hubris, as one simply describes "things as they are", while in fact the vision is based on a myth, stricto sensu. Indeed, there is no myth without the notion that what we see and do results from a pre-existing totalising nature, which functions as a founding principle, as a model, as a necessary template for future action (Rosset, 1986, p. 28-9).

The other side of this natura naturans is not just prejudice (which abolishes fluidity to the extent that prejudice roots "us" and "them" to a specific place and time), but also a deep sense of inevitability. Characteristically, after his party's landslide victory in the 2011 Holyrood election, ${ }^{29}$ Alex Salmond predicted that "the destination of independence is more or less inevitable" (Maddox, 9 May 2011). ${ }^{30}$ This is however in essence a teleological approach to history and politics (shared, surprisingly, by, among others, Scottish historian Tom Nairn ${ }^{31}$ ), as though both were linear progressions.

Scottish Nationalists, it seems, have of late realised they are in a quandary on the identity and England/Scotland questions. As pointed out by journalist Kenny Farquharson (18 March 2012), the Scottish First

29. The SNP took $45.4 \%$ of the constituency vote and $44.7 \%$ of the regional vote in the 2011 Scottish election.

30. Likewise, on 31 May 2012, winding up the proceedings for the Scottish government during the debate on "Scotland's Future" at Holyrood (a debate broadcast by BBC Parliament on 4 June 2012), N. Sturgeon insisted that independence was Scotland's "natural future".

31. See e.g. T. Nairn, "It's pointless to hold back the tide of history", The Scotsman, 17 January 2012. 
Minister is currently trying to get the SNP to embrace Britishness by insisting an independent Scotland would defend a "cultural and social union" with England, and would proudly keep the Queen as head of state, share British embassies around the world, share military functions and bases with the British armed forces, use the pound as its currency, and have the Bank of England overseeing monetary policy.

This is in line with a poll by YouGov that has shown Scots have warmed to the idea of Scotland running its own tax affairs under a system of "fiscal autonomy", while backing for British institutions such as the monarchy $(60 \%$, up $5 \%$ on 2008$)$, the pound $(82 \%$, up $9 \%)$, the British army (67\%, up 1\%) and even the nationwide BBC Six O'Clock News $(63 \%$, up $3 \%$ ) or a Britain-wide Olympic team $(54 \%$, up $3 \%$ ) has risen too. Conversely, only $28 \%$ said they wanted Scotland to have its own immigration laws (down 8\%) (Barnes, 7 March 2012).

Unfortunately for the SNP, a social union would be, as it were, null and void without a measure of equalisation of rights and duties, or without a form of redistribution (unless the whole point is merely to keep in touch with/visit friends or family in Newcastle or Corby), all of which is hardly conceivable with no overarching framework for (fiscal and political) power sharing. This is probably the ultimate double bind in their narrative that the Nationalists must now address.

\section{Bibliography}

\section{Books and articles}

Appert Manuel, Bailoni Mark, and Papin Delphine, Atlas de Londres (Une métropole en pleine mutation), Paris, Eds Autrement, 2012, 96 p.

Bedford Colin, Weep for the City, Tring (Herts), Lion Publishing, 1982, 127 p.

Bugler Simon, "The Culture of Poverty Thesis and Urban Poverty: Shades of Myth and Reality", in Monica Charlot (ed.), Britain's Inner Cities, Gap and Paris, Ophrys-Ploton, 1994, p. 23-41.

Canivez Patrice, Qu'est-ce que la nation?, Paris, Libraire philosophique J. Vrin, 2004, 126 p.

Chartier Roger, Au bord de la falaise. L'histoire entre certitudes et inquiétude, Paris, Albin Michel, 2009 (revised edition; 1998), 384 p.

Civardi Christian, L'Écosse depuis 1528, Paris, Ophrys, 2000.

Coleman Terry, Thatcher's Britain: A Journey through the Promised Lands, London, Corgi Books, 1988 (1987), 200 p. 
Convery Paul, "Unemployment", in Alan Walker and Carol Walker (eds), Britain Divided: The Growth of Social Exclusion in the 1980s and 1990s, London, Child Poverty Action Group, 1997, pp. 170-97.

Cuthbert Jim and Cuthbert Margaret, "SNP Economic Strategy: NeoLiberalism with a Heart", in Gerry Hassan (ed.), The Modern SNP: From Protest to Power, Edinburgh, Edinburgh University Press, 2009, pp. 105-19.

Delannoi Gil, La Nation, Paris, Le Cavalier Bleu, 2010, 127 p.

Dixon Keith and Christoph Gilles, "De Londres à Saint Andrews: Les matrices institutionnelles du néolibéralisme britannique", Textes \&̊ contextes, no. 5 ("Stéréotypes en langue et en discours"), 29 March 2011 (available online: <http://revuesshs.u-bourgogne.fr/textes\&contextes/ document.php?id=1253 ISSN 1961-991X>).

DuPIN Éric, L'hystérie identitaire, Paris, Le Cherche midi, 2004, 167 p.

Escott Karen, Price Christopher, Buckner Lisa, and Shipton Lucy, Addressing Women's Poverty in Southwark: Local Labour Market Initiatives, Sheffield, Centre for Social Inclusion - Sheffield Hallam University, 2006, 32 p.

English Tom, The Grudge: Scotland vs. England, 1990, London, Yellow Jersey Press, 2010, 260 p.

Garnham Alison, Howard Marilyn, Fimister Geoff, and Veit-Wilson John, Poverty: The Facts, London, Child Poverty Action Group, 2001 (4th edition), $216 \mathrm{p}$.

Hackett Fischer David, Historians' Fallacies: Toward a Logic of Historical Thought, New York, Harper and Row Publishers, 1970, 338 p.

Harrison Paul, Inside the Inner City: Life under the cutting edge, London, Penguin Books, 1988 (1985 - revised edition; 1983), 446 p.

Hassan Gerry, "The Making of the Modern SNP: From Protest to Power", in Gerry Hassan (ed.), The Modern SNP: From Protest to Power, Edinburgh, Edinburgh University Press, 2009, pp. 1-18.

HiLls John, "How will the scissors close? Options for UK social spending", in Alan Walker and Carol Walker (eds), Britain Divided: The Growth of Social Exclusion in the 1980s and 1990s, London, Child Poverty Action Group, 1997, pp. 231-48.

Jeffery Charlie, "Devolution, Social Citizenship, and Territorial Culture: Equity and Diversity in the Anglo-Scottish Relationship", in William L. Miller (ed.), Anglo-Scottish Relations from 1900 to Devolution and Beyond, Oxford, Proceedings of The British Academy (128) published by Oxford University Press, 2005, pp. 113-29.

KIDD Colin, British Identities before Nationalism: Ethnicity and Nationhood in the Atlantic World, 1600-1800, Cambridge, Cambridge University Press, 1999, 302 p. 
LindsaY Isobel, "The SNP and Westminster", in Gerry Hassan (ed.), The Modern SNP: From Protest to Power, Edinburgh, Edinburgh University Press, 2009, pp. 93-104.

Maxwell Stephen, "Social Justice and the SNP", in Gerry Hassan (ed.), The Modern SNP: From Protest to Power, Edinburgh, Edinburgh University Press, 2009, pp. 120-34.

Mitchell James, "Contemporary Unionism", in Catriona M. M. MacDonald (ed.), Unionist Scotland 1800-1997, Edinburgh, John Donald Publishers, 1998, p. 117-39.

Parekh Anushree, MacInnes Tom, and Kenway Peter, Monitoring poverty and social exclusion 2010, York, Joseph Rowntree Foundation and New Policy Institute, 2010, 115 p.

Poutignat Philippe and Streiff-Fenart Jocelyne, Théories de l'ethnicité, Paris, Presses universitaires de France, 1995, 270 p.

Riceur Paul, Soi-même comme un autre, Paris, Seuil, 1990, 428 p.

Rosset Clément, L'Anti-nature : Éléments pour une philosophie tragique, Paris, PUF, 1986 (1973), 330 p.

Smith Anthony D., National Identity, London, Penguin Books, 1991, 227 p. Tomaney John, "In Search of English Regionalism: the Case of the North East", Scottish Affairs, no. 28, Summer 1999, pp. 62-82.

Torrance David, "We in Scotland": Thatcherism in a Cold Climate, Edinburgh, Birlinn Ltd., 2009, 324 p.

Touraine Alain, "Faux et vrais problèmes", in Michel Wieviorka (ed.), Une société fragmentée? Le multiculturalisme en débat, Paris, La Découverte, 1997 (1996), pp. 291-319.

Trench Alan (ed.), Devolution and higher education: impact and future trends (Research Report), London, Universities UK, December 2009, 57 p.

Veyne Paul, Comment on écrit l'Histoire, Paris, Seuil, 1996 (1971), 439 p.

Weight Richard, Patriots: National Identity in Britain 1940-2000, London, Pan Books, 2003 (2002), 866 p.

Wieviorka Michel, La Différence, Paris, Balland, 2001, 201 p.

\section{Newspaper articles}

A. G., "Spiffy Scots", The Economist, 30 March 2012, <www.economist. com/blogs/blighty/2012/03/scottish-universities $>$.

"Alex Salmond hails 'spirit of community' in Christmas message", The Scotsman, 23 December 2011, <www.scotsman.com/news/politics/ top-stories/alex-salmond-hails-spirit-of-community-in-christmasmessage-1-2023202>.

BARnes Eddie, "Scottish independence poll: Scottish support for UK institutions grows", The Scotsman, 7 March 2012, <www.scotsman.com/ 
the-scotsman/politics/scottish-independence-poll-scottish-supportfor-uk-institutions-grows-1-2156240>.

CARrell Severin, "England riots: Alex Salmond angry as 'UK' headlines sweep Scotland into fray", The Guardian, 10 August 2011, <www. guardian.co.uk/uk/2011/aug/10/england-riots-salmond-ukheadlines $>$.

"Independent Scotland would be beacon of progressive opinion, says Salmond", The Guardian, 23 January 2012, <www.guardian.co.uk/ politics/2012/jan/23/independent-scotland-beacon-progressiveopinion>.

Chisholm Malcolm, "Flying the flag for greatest possible devolution", The Scotsman, 24 November 2011, <www.scotsman.com/the-scotsman/ opinion/comment/flying-the-flag-for-greatest-possible-devolution1-1980980>.

Clark Tom, "Conservative support shrinks as voters turn against NHS reforms", The Guardian, 20 February 2012, <www.guardian.co.uk/ politics/2012/feb/20/conservative-support-shrinks-voters-nhs>.

CurTice John, "Time to make a devo deal", The Scotsman, 25 January 2012, <www.scotsman.com/the-scotsman/opinion/comment/johncurtice-time-to-make-a-devo-deal-1-2075593>.

Davis Rowenna, "Working-class revolution not reaching 'posh' universities", The Guardian, 28 September 2010, <www.guardian.co.uk/ education/2010/sep/28/working-class-students-posh-universities>.

"England unfairly treated by 'stale Union' says Salmond", The Scotsman, 20 March 2007, <www.scotsman.com/news/scottish-news/top-stories/ england-unfairly-treated-by-stale-union-says-salmond-1-1341655>.

FarQuharson Kenny, "Cultural revolution as SNP learns to love the Brits", Scotland on Sunday, 18 March 2012, <www.scotsman.com/ scotland-on-sunday/opinion/comment/kenny-farquharson-culturalrevolution-as-snp-learns-to-love-the-brits-1-2180450>.

GentLEMAn Amelia, "Budget 2012: struggle continues while factory makes Range Rovers for the rich", The Guardian, 21 March 2012, <www. guardian.co.uk/uk/2012/mar/21/budget-halewood-range-roversfor-the-rich>.

Hassan Gerry, "In search of a modern Scotland of love and equality", The Scotsman, 3 December 2011, <www.scotsman.com/the-scotsman/ opinion/comment/gerry-hassan-in-search-of-a-modern-scotland-oflove-and-equality-1-1990573>.

- "The fourth most unequal country in the world", The Scotsman, 17 March 2012, <http://www.scotsman.com/the-scotsman/opinion/ comment/gerry-hassan-the-fourth-most-unequal-country-in-theworld-1-2178654>. 
JefFery Charlie, "A gamble that may well pay off for Alex Salmond", The Scotsman, 6 May 2011.

LeE David and McLeod Fiona, "Mike Russell gives his backing to 'trust' schools", The Scotsman, 15 February 2010, <www.scotsman.com/news/ education / mike-russell-gives-his-backing-to-trust-schools- 1 790676>.

MaLeish Henry, "Saying No to independence is not enough", The Scotsman, 28 January 2012, <http://www.scotsman.com/the-scotsman/ opinion/comment/analysis-saying-no-to-independence-is-notenough-1-2083444>.

Macnab Scott, "Religious hate crime 'hits four-year high", The Scotsman, 22 November 2011, <www.scotsman.com/the-scotsman/politics/ religious-hate-crime-hits-four-year-high-1-1973881>.

-, "SNP set to scrap right to buy council homes in Scotland", The Scotsman, 8 June 2012, <www.scotsman.com/the-scotsman/uk/snpset-to-scrap-right-to-buy-council-homes-in-scotland-1-2344548>.

MAdDox David, "Independence now inevitable - Alex Salmond", The Scotsman, 9 May 2011, reprinted at <www.martinfrost.ws/htmlfiles/ scotnews 1 1/110509-inevitable.html>.

"Mike Russell gives his backing to trust schools", The Scotsman, 14 February 2010, <www.scotsman.com/news/education/mike-russell-gives-hisbacking-to-trust-schools-1-790676>.

NAIRN Tom, "It's pointless to hold back the tide of history", The Scotsman, 17 January 2012, <www.scotsman.com/the-scotsman/ opinion/comment/tom-nairn-it-s-pointless-to-hold-back-the-tide-ofhistory-1-2060011>.

Peterkin Tom, "Scots voters support student tuition fees", The Scotsman, 21 April 2011, reprinted at <www.martinfrost.ws/htmlfiles/scotnews 11/110421-support.html>.

"Scotland loses 50,000 jobs in health and social work", The Scotsman, 16 March 2012, <www.scotsman.com/the-scotsman/health/scotlandloses-50-000-jobs-in-health-and-social-work-1-2177128>.

"Scots home ownership doubles", BBC News, 25 January 2003, <http:// news.bbc.co.uk/2/hi/uk_news/scotland/2692249.stm>.

"SNP conference: Scots will vote for independence - Sturgeon", The Scotsman, 21 October 2011, <www.scotsman.com/news/politics/topstories/snp-conference-scots-will-vote-for-independence-sturgeon-1-1924032>.

SWANSON Ian, "Will affair with SNP go the distance?", Edinburgh Evening News, 8 March 2012, <www.scotsman.com/edinburgh-evening-news/ opinion/ian-swanson-will-affair-with-snp-go-the-distance-1$2160826>$. 
TRAVIS Alan, "Thatcher government toyed with evacuating Liverpool after 1981 riots", The Guardian, 30 December 2011, <www.guardian. co.uk/uk/2011/dec/30/thatcher-government-liverpool-riots-1981>.

Trench Alan, "Involved voters like devolved parties", The Scotsman, 4 October 2011, <www.scotsman.com/the-scotsman/opinion/comment/alan-trench-involved-voters-like-devolved-parties-1-1889702>.

"UK might slip to the right but Scots still remember Thatcher", The Scotsman, 29 January 2010, <www.scotsman.com/news/politics/topstories/uk-might-slip-to-the-right-but-scots-still-remember-thatcher1-1229346>.

Whitaker Andrew, "London control of referendum would be insult McLeish", The Scotsman, 22 November 2011, <www.scotsman.com/ the-scotsman/politics/london-control-of-referendum-would-beinsult-mcleish-1-1978035>.

"Why border issue could be barrier to split", The Scotsman, 15 December 2006, <www.scotsman.com/news/politics/top-stories/why-borderissue-could-be-barrier-to-split-1-734384>.

Young Hugo, "The pledge that Blair must be cursing", The Guardian, 11 February 1997.

\section{Hansard parliamentary debates (House of Commons)}

"Unemployed Persons" - 16 December 1975 (vol. 902, c. 593W).

"Devolution [Scotland And Wales]" - 19 January 1976 (vol. 903, c. 1042).

"Debate on the Scotland and Wales Bill" - 14 December 1976 (vol. 922, c. 1358).

"Scotland Act 1978 (Repeal)", 20 June 1979 (vol. 968, c. 1378).

"National Health Service Hospitals [Opting Out]" - 21 March 1990 (vol. 169, cc. 1121-2).

"Privatisation" - 11 May 1992 (vol. 207, c. 458).

\section{HMSO reports}

Census 1981: Economic activity in Great Britain, 1984.

\section{Internet sources}

Your Scotland - Your Referendum: A Consultation Document, 25 January 2012, $<$ www.scotland.gov.uk/Publications/2012/01/1006/>.

"The changing face of home-ownership in Scotland", London, Council of Mortgage Lenders, 2006, <www.cml.org.uk/.../04Thechanging faceofhome-o...>. 